\title{
The Role of Social Bricoleurs in Crafting Civil Solidarity during the
}

\section{COVID-19 Pandemic}

\section{Ivy Pricilia Gabriela Londa; Karina Dwita Shafira}

Warwick Manufacturing Group,

University of Warwick, United Kingdom;

Civil Engineering, Institut Teknologi Bandung, Indonesia

ivy.londa@gmail.com

The impact of the COVID 19 Pandemic has arguably been inflicted largely in the economic sector than in the health sector. People are suffering every day with millions losing jobs and fall into poverty especially in developing countries. While each government is saving the world from the global recession, the need for local lifeboat initiatives is imperative to contribute to the local economy. If not assisting the country from the severe national recession, it helps vulnerable groups and individuals to survive the global recession. The social bricoleur is a type of social enterprise characterized by its self-governing nature to venture opportunities using the readily available resources based on their tacit position in the social fabric. The research is investigating how solidarity in response to COVID-19 can be enabled by engineering ecosystem orchestration and management through social bricoleur initiatives. The study was conducted with an exploratory single case study to gain insights on how social bricoleurs play a part in addressing social gaps, using the Bagirata platform who operates in response to the COVID-19 economy as a collective effort of wealth redistribution. This middle-class society is the largest in numbers for major cities in Indonesia where the social wealth is the weakest and the population density is the highest, therefore might result in a more fractious society and prone to more social conflict. This class of society also indicates potentials for development programs, rather than the cash-transfer programs that the government has taken such measure recently. No solution fits all, the solidarity calls are inclined to create as many as solutions possible we could create with our resources.

Keywords: open innovation; social bricoleurs; solidarity orchestration; social value co-creation; innovation management

\section{Introduction}

The world is under pressure by the Coronavirus since The World Health Organization (WHO) declared COVID-19 as a global pandemic on March 11, 2020 (World Health Organization, 2020). The current pandemic is caused by the third Coronavirus outbreak in the past two decades. Ceylan
\& Ozkan (2020) observed the economic effect of the outbreak caused by the previous Coronavirus. However, the first Coronavirus outbreak, Severe Acute Respiratory Syndrome (SARS), did not affect GDP seriously. The most visible decline was observed from the initial SARS-COV attack was in Hong Kong, with a 2,79\% decrease in GDP from 2002 to 
2003. Furthermore, the study suggested that the second Coronavirus's impact that caused Middle East Respiratory Syndrome (MERS) was more visible. Real per capita GDP in Saudi Arabia, Qatar, UAE, and Kuwait plummeted by $16 \%, 25 \%, 12 \%$, and $32 \%$, respectively. The Coronavirus is not only wrecking the economic condition but also reshaping worldwide governance and democracies. In the Global South itself, several issues such as food insecurity and domestic violence in SubSaharan Africa empowered authoritarian and extreme poverty in South and Central Asia, and propaganda wars are currently on the rise in East Asia and the Pacific (World101, 2021). On the other hand, studies have found that 61 percent of nations "implemented restrictions that were either illegal, disproportionate, indefinite or unnecessary" in at least one area of democratic freedoms ("Pandemic putting democracy under threat: Study," 2020).

Indonesia, along with other countries, imposed several non-pharmaceutical interventions (NPIs) like "PSBB (Pembatasan Sosial Berskala Besar) or stay-at-home" orders to mitigate the spread of COVID-19. NPIs can be crucial in decreasing local peak mortality and cumulative mortality (Barro, Ursúa, \& Weng, 2020; Hatchett, Mecher, \& Lipsitch, 2007; Markel et al., 2007). Some countries in the Global South, such as Thailand and Vietnam, had acted decisively towards this pandemic by implementing NPIs early when the number of infection cases was still low. Unlike Indonesia, Thailand, and Vietnam enacted NPIs measures such as shutting down the border and suspending all travelers, including returning citizens from entering when the number of cases was still low, has shown significant tremendous results in handling the COVID-19 pandemic (Shalihah, 2020).

For Indonesia, the impact of the national NPI has not proved to flatten the curve of COVID-19 infection rate and the policies that have been recently imposed again for the second PSBB in Jakarta (Tri, 2020) at the cost of the national economy. The Indonesian Government's management in facing the COVID-19 pandemic has resulted in a decline of democracy indicator in 2020 (Pepinsky, 2021). However, a study has found that around $85 \%$ of Indonesians remain satisfied with the performance of its current President in office. Although there was a modest decline relative to the pre-COVID-19 level, the satisfaction remained quite high and President Widodo remained popular. The government has a taken various political decision in combating the outbreak and its economic effect such as cabinet reshuffling, including assigning his opposition in the previous election as minister of tourism and creative economy (Voi Editorial Team, 2020), and banning the controversial Islam Defenders Group (FPI) (Da Costa \& Lamb, 2020) which then creates some tension between Indonesia's Islamists.

During the COVID-19 economy, Indonesia's GDP in the second quarter of 2020 (Q2) contracted by $5.32 \%$, the lowest since the first quarter of 1999, due to disruption of the business and household that leverages the state revenue during the global pandemic. Finance Minister Sri Mulyani predicts that Indonesia's economy will remain contracted from between 2.9 to 1.1 percent in the third quarter (Q3) of 2020 (Pangastuti, 2020). According to the Chamber of Commerce and Industry (CNN 
Indonesia, 2020), the number of people who lost their jobs due to the COVID-19 economic recession as of May 2020 already reached 15 million. As the national recession becomes near impossible to evade, the unemployment rate will become higher, and millions of people will fall below the National Poverty Line. In 2021, where vaccination already began to take place, Indonesia cut its interest rate to a new all-time low since the focus has shifted from pandemic relief programs to maintain economic stability and boost the national economic recovery momentum (Jiao \& Sihombing, 2021).

The COVID-19 pandemic has become a significant shock for the economic climate and causes tremendous job loss in Indonesia, affecting those in the urban area where the majority of the middle-class population lives. The Indonesian government has launched various social aid disbursements in Food Aid Program, such as Sembako and Staple Food Card, free electricity and discount for poor households, and Direct-Cash-Assistance such as BLT and Pre-Employment Card to assist support for the public (Ihsanuddin, 2020; Nuky, 2020). However, this program has been criticized due to some flaws in the system which caused the delay in disbursement (Gorbiano, 2020b). The inefficiencies in aid distribution also expose bad governance due to a lack of reliable data for targeted recipients, as well as a lack of coordination among regional and central governments (Gorbiano, 2020a). In December 2020, Indonesia's Social Minister, Juliari Batubara was arrested due to a corruption suspect for COVID-19 social aid, moreover, the Indonesian Corruption Watch suspected that the corruption was planned before there was no
COVID-19 suspect in Indonesia (Firdaus, 2021).

Responding to the global COVID-19 pandemic and the urgency to innovatively tackle multidimensional social problems both at the local and regional level, this paper explores the role of social bricoleurs in responding to the socio-economic problems as a result of the pandemic. It will be done through a case study methodology by investigating a social venture that operates within the concept of co-creation and civil solidarity. Initial data is gathered from the beneficiary's perspective to gain insights needed to amplify the impact of such initiatives.

\section{Literature Overview}

The Rise of Middle Class in Indonesia

This section aims to identify the role of middle-class society in the political salience in Indonesia. The rising of middle-class society is linked to economic growth and also plays important social and political roles, which have consequences not only for growth but also for governance and policy. In the past 50 years, Indonesia has seen strong economic growth and a substantial decrease in extreme poverty, with growth averaging 5.6\% annually. World Bank (2019) recorded the growth of Indonesia economy, using the National Poverty Line (a combination of household survey data or SUSENAS and World Bank calculation) methodology, showed rapid growth in the middle-class representing half of the household consumption in Indonesia, which become the critical component of economic growth. The report classifies the socio-economic class based on per capita consumption monthly as Poor (< Rp. 354K), Vulnerable (Rp. 354-532K), Aspiring Middle Class (Rp. 532K-1.2M), 
Middle-Class subcategory 1 (Rp. 1.2-3.2M), Middle-Class subcategory 2 (Rp. 3.2-6M), and Upper Class (>Rp. 6M). The rising population of the Middle Class influences various pivotal societal enhancement such as the dynamics of social mobility, the sources of entrepreneurship and job creation strengthening social cohesion, and enhancing political stability (Consumer Business, 2015; World Bank, 2019)

World Bank (2019) drew a link between the sociopolitical role that the Middle-Class plays and economic policies. Lipset (1959) argued that affluent societies are more in favor to create and consolidate democracies. The Middle-Class has been perceived to be more politically active and tends to take part in political activities than both the lower and upper class (Amoranto, Chun, \& Deolalikar, 2010). However, Middle-Classes' support for political and economic reform may only hold if it is aligned with the benefits of its members. The report further suggests that without a comprehensive and effective social protection system, all the middle classes are vulnerable to an economic shock (Consumer Business, 2015; World Bank, 2019). They will easily fall back to the lower class and hard to emerge from the transient poor status. The report further argues that inclusive growth is prominent to provide economic mobility and highlights the risk that if the middle class fails to expand to include the millions more who aspire to join, it will result in a more polarized and fractious society. The political salience of the Middle-Class in economic and political reform can be seen during the COVID-19 Pandemic in voicing the concern on how governments handle the crisis. Black
Lives Matter is among other movements that enhanced racial inclusivity which happened in the Global North. Various protests, some cases lead to a successful reformation such in Thailand where people call for monarchy reform, appeared on many occasions in Global South countries such as China, and Africa, in response to the government's measures in handling the COVID-19 (Spier, 2020; Xie, 2020)

\section{$\underline{\text { Social Bricoleur as a Solidarity Initiative }}$}

This section attempts to understand the crafting of solidarity in response to the COVID-19 can be conceptualized and practiced by the term 'double movement' as an expression borrowed from Polanyi that internalized the tension between "substantivalism" and "formalism". While the reasoning between the national economy and the remaining effort to be united in our shared humanity is at play, the precise balance between these opposing tendencies is contingent upon the configuration of political force in given political circumstances. The COVID-19 Pandemic is believed to be a wake-up call for multilateralism, despite the UN General Assembly initiative of Global Solidarity to Fight COVID-19 call for international solidarity (Ministry of Foreign Affairs of the Republic of Indonesia, 2020), many criticized the lack of inclusive multilateral efforts (Perthes, 2020; Santiago, 2020). Askary \& Fallah (2020) argues that the difficulties arising from the COVID-19 pandemic have demonstrated that crafting global solidarity during this crisis is currently at risk, previous research established that human rights on solidarity have been violated. In the regional context, despite rather swift regional efforts such 
as the EU's support for its own severely affected member states, ASEAN remains silent and focuses on regaining individual power (Perthes, 2020; Santiago, 2020).

Weber (2007) argued that the concept of solidarity could be explored in many ways rather than one global context, emphasizing the connotation of collective moral agency and transformative account of political struggles attributed with it. Identifying tensions working within those concepts and locating tensions within the broader political-economic landscape in the COVID-19 situation helps us to see innovative perspectives in crafting solidarity to balance both economic recovery and common social goals. There are two approaches in understanding the conceptual tensions in Polanyi's double movement, formal and substantive. The former assumes that the economy operates in the logic of means-ends relationships, where the actual needs of the community are the primary reason for economic activities. Whereas the formalists account for the market as self-regulating and separate the market from other social structures, assuming the market that operates on its own is capable of organizing society. Nurshafira \& Alvian (2018) compared the interplay of the economic tensions in the Global North and Indonesia represents a fundamental difference in the configuration of power. While the Global North disseminates equal power in the tension between formal and substantive economy, the Indonesian context tends to show an inclination towards the formal principle of economy.

In Indonesia, the economic nationalism discourse of Widodo's administration aims to protect the local business from foreign competition and gives rise to social enterprise.
Increasingly being described as "a social and solidarity economy" (Bénédicte Fonteneau, Leandro, \& Morais, 2020), social enterprise comprises organizations and enterprises with social and often environmental objectives, guided by principles and practices of cooperation, solidarity, and democratic self-management.

Polanyi demonstrates that the expansion of the market is always in conflict with social protection. In response to the urgency to recover from the COVID-19 Pandemic, this highlights the opportunities on the rise of social and solidarity economy and the importance of social entrepreneurship as tools in crafting solidarity covering the socialization process through which social and political orders are stabilized and reproduced.

It is argued that the Indonesian middle class has been a significant driver of economic growth as it helped accelerate consumption growth in the national accounts and the source of entrepreneurship (Consumer Business, 2015; World Bank, 2019). Despite comprising only $20 \%$ of the population, the middle class represents half of the business owner who creates jobs for others (World Bank, 2019). The social bricoleur is a term built based on Hayek's (1945) concept of contextual role in the entrepreneurial process. Often crafted on a small scale and limited scope, social bricoleurs play an essential role in addressing unrecognizable social needs and provide simple collaborative solutions in their local communities. In terms of venture management, social bricoleurs typically operate with readily harnessed resources and do not require external or specialized resources (Weick, 1993) which distinguish them from other types of altruistic entrepreneurs - on the 
other hand, improvising on available resources rather than formal planning. Nevertheless, the independent nature of social bricoleurs allows them to operate freely to impose their agenda, which can be efficiently self-correcting and freely collaborating with other ventures or social bricoleurs (Pfeffer \& Salancik, 2003). Due to its autonomous nature, social bricoleurs' entrepreneurial action to address the social gap is an expression of active civil participatory where citizens have the power to address issues of public concern.

Often crafted on a small scale and limited scope, social bricoleurs play an essential role in addressing unrecognizable social needs and provide simple collaborative solutions in their local communities. Thus, the notion of social bricoleurs collaboration in solidarity also in line with the long-established Indonesian cultural value of cooperation ("Gotong royong"). As a value that has to shape Indonesian social fabric and has been deeply rooted in the Indonesian society's life (Simarmata et al., 2020), solidary initiated by the social bricoleur (individuals or venture-driven) in times of crisis such as COVID-19 pandemic situation is imperative to tackle social problems and filling the local gap where the state fails to address.

The Concept of Solidarity Co-Creation as Shared Value Orchestration

This section aims to explore how solidarity can be co-created through innovation principles. Gaztambide-Fernández (2020) highlighted important aspects in crafting solidarity that involves ethical and political commitments, otherwise, solidarity might turn against us by sacrificing the vulnerable groups. Chesbrough (2020) and Munshi (2010) (as cited in Ratten, 2020) believe in combining shared value creation of social innovation and entrepreneurship, which studies believe will drive to faster recovery from the effects of COVID-19. However, the Indonesian government's political mindset about innovation has failed to demonstrate the significant transformation that is up to date with the changing paradigm of innovation (Curley \& Salmelin, 2018). In the Global North, the practice of Open Innovation 2.0 is encouraged and or even softly regulated by the government (OECD, 2017). Open Innovation 2.0 concept around the idea of shared value and focused on adoption (Porter \& Kramer, 2011), it is characterized by the orchestration of shared value and vision, quadruple helix innovation, usage of co-creation platform, and innovation ecosystem management (Curley \& Salmelin, 2013). The older concept of open innovation combines internal and external ideas into the business model and utilizes it to create value and enable ideas (Chesbrough, 2003). In the Southeast Asia region, recent data (Unesco Institute for Statistics, n.d.) showed that Indonesia's research budget is only $0,2 \%$ of its GDP, behind Thailand $(0,5 \%)$ and Vietnam $(0,4 \%)$. During the challenging time, an openness to innovative strategy and the investment in knowledge and technology orchestration may play a pivotal role in fostering the COVID-19 recovery.

The rising middle class in Indonesia offers the opportunity for innovative active citizenship or also known as civil participatory, where people are involved in finding a way about how to help society by launching their 
social action project (British Council, 2017). Dalton (2017) suggests that there is a positive correlation between citizen participation and the functioning of government. On the other hand, the rising level of active participation also makes governing more complex because it could slow down the decision-making process. However, the aim of democracy itself is not measured by the level of efficiency, but to balance social interest which led to better decisions. The tacit knowledge of the social bricoleurs in the social fabric provides them the opportunity to venture into the social gap that needs to be addressed. Nonetheless, good governance on the principle of open innovation, social innovation, and entrepreneurship can be adopted to orchestrate the shared value and foster the COVID-19 recovery.

\section{Methodology and Data Collection}

Bagirata (www.bagirata.id) is an independent social bricoleur initiative launched in April 2020 that uses a digital prototype of a multi-sided platform (peer-to-peer wealth distribution) to raise civil solidarity for social value co-creation in response to NPI taken by the Indonesian government, which caused massive income disruption to many income households following the COVID-19 outbreak. The platform targets grey collars groups (informal workers) that mainly reside in the urban area to articulate their financial aid needs. Responding to it, the public uses Bagirata to express their solidarity by cash transfer directly to the beneficiaries' digital wallets. Breathing in the notion of personal data ownership rights and using readily available open access data such as digital wallet information and other open collaborative platforms, Bagirata facilitates the interaction between social classes and strengthens societal cohesion in response to the economic situation dynamics that have suffered during the COVID-19 pandemic. The platform distributed almost half-billion rupiah in six months, acquiring more than 1500 beneficiaries database that majority lives in urban areas and distributing cashtransfer directly to beneficiaries from more than 2000 individual public donors (MetroTV, 2020; Utama, 2020). Bagirata demonstrates a desirable miniature that can be copied on a national level while applying innovation principles to address social gaps and enabling solidarity orchestration through shared value co-creation. A role of where good governance from the state should take place is taken by social bricoleur, establishing the importance to nurture a socio-political climate that might enable more active citizenship initiatives.

Exploratory research has been conducted to gain initial insight from COVID-19 economy victims, using the Bagirata platform as data entry to the sample population. The targeted local survey deems to be more appropriate to capture the middle-class society in Indonesia rather than snowballing sampling, considering the captivity of the participants that fit with the criteria of the insights needed from the beneficiaries. The majority of Bagirata users are digital savvy, digital wallet owners, and the majority live in first-tier cities. This characteristic concluded that the middle-class profile classification should, therefore, represent class behavior (Consumer Business, 2015). We examined the beneficiaries' database and identified six 
informal sectors whose jobs were impacted by the economic shock. The major sectors are food and beverages, tourism, media, logistics, event and entertainment, and creative. Of the study population, further, we conducted quantitative and qualitative research through surveys to 332 respondents' that previously obtained from Bagirata's database to collect demographic information and investigate the social condition, challenge, and opportunities of the targeted social class and preferred intervention needed by the respondents in regards to the effect of COVID-19 economy. Analyzing through the lens of innovation principles and contextualizing it in the Pandemic sociopolitical context, we explore some workable insights on how social bricoleur might be enabled as part of active civil participatory that may craft solidarity movement in response to the COVID-19 Pandemic.

\section{Results}

Looking at the result, the majority of the respondents (40\%) are aged $23-27$, while $26 \%$ are aged $28-32$. It also can be seen that most of the respondents are male $(70 \%)$, while the females only third-tenth of the samples. The first goal analysis that we consider from this survey is to investigate the purchasing power of the people whose jobs are affected by the pandemic. Knowing the purchasing power will help us to classify the respondent based on their monthly expense according to the World Bank classification. Our survey suggested that the average monthly expense is around. 3.2 million IDR. Furthermore, we collect income ranges from the respondent before and after COVID-19 to examine the impact of NPI on the impacted workers. $80 \%$ of the respondents stated that their job was disrupted right after the first NPI, which was in March and April 2020. 65\% become jobless due to contract termination or forced to take unpaid leave, $15 \%$ experience income decline due to a low number of sales, and $13 \%$ of jobs were canceled or postponed to further notice, leaving them in household economic shock. Despite the high cost of living in the urban area ( $42 \%$ lives in rent room accommodation), $82 \%$ of those who were surveyed indicated that they are still living in the previous accommodation while the remains were relocated to rural areas to live with their relatives and to decrease their cost of living significantly.

$$
\text { A minority of participants (10\%) }
$$
indicated that they are back in the workforce, probably after the loosen NPI was taken by the government known as the PSBB transition period. Nevertheless, the majority of the samples are still struggling to cover their dayto-day living costs. Almost two-thirds of the participants $(57 \%)$ stated that they are now incomed around IDR 1-2 million monthly. The survey indicates that respondents' source of income during a pandemic is from temporary miscellaneous jobs, online selling, or stayed in previous jobs with a significant reduction of monthly income. We also found various mentions of government assistance such as logistic aid (Sembako) and the Pre-employment card benefit program that was launched by the government to respond to the COVID-19 economic impact, although some concerns were expressed regarding the distribution of the government's social aid.

Further, we asked qualitative questions 
to probe the creativity of the beneficiaries based on their skills and ability to generate temporary income. The majority of the respondents commented that they are willing to start a food and beverage business, joining an ondemand delivery service, or providing design service for promotional content. When the participants were asked to articulate the most necessary non-monetary assistance according to their current condition, the majority $(70 \%)$ commented that the most desirable supports are related to entrepreneurship training and capital loan to start a small business.

In assessing how the management of change can be implemented, we investigate the psychological impact of the recent global pandemic that has been brought to them. Articulating from Kübler-Ross'(1997) five stages of grief, which are denial, anger, bargaining, depression, and acceptance, we asked the participants to describe their mental response to the COVID-19 situation. From a holistic change management approach, the transformation cycle helps us to decide what support is needed by the beneficiary in accelerating change. Transformation planning and preparation are needed to help those in depression, anger, and denial stages to move forward into the acceptance and exploration stage where they could be empowered in rebuilding the society (Deloitte, 2020).

A variety of perspectives were expressed that they are in denial phase with the prolonged COVID-19 impacts (35\%), one-third of the participants (30\%) stated that they are currently feeling depressed due to the weakening job market, $21 \%$ in the bargaining phase as they expressed the readiness to explore a new job industry in mitigating the impacted economy, whilst the minority (4\%) are still in the anger phase. On the other hand, $10 \%$ stated that they are already in the acceptance phase by expressing that they have plans to execute in response to the prolonged COVID-19 situation. Understanding the appetite for support and inquiring about the capture of psychological state helped us to understand the mental support needed by the community to be able to continue thriving.

The local survey can be replicated in the larger population to capture the struggle of Indonesian middle-class economy dynamics in the COVID-19 economy, worsening by the inevitable incoming recession (IDNFinancials, 2020). In summary, the survey concludes that the majority of our respondents have experienced transient poverty because of the ongoing global pandemic. Transient poverty is the component of time-mean consumption poverty at the household level that is directly attributable to the variability in consumption; this can be thought of as a measure of vulnerability to falling consumption (Jalan \& Ravallion, 2007). Together these results provide important insights to map several challenges and opportunities faced by COVID-19 impacted workers to emerge from transient poverty, thus informing social bricoleur's responses to enact solidarity interventions or social ventures activity in the area that might be overlooked by the government.

\section{Discussions}

Unseen Population Issue in Cash-Transfer $\underline{\text { Interventions }}$

The findings in this section aim to draw a correlation between the impact that 
has been brought by the COVID-19 economy on the rising Middle Class in Indonesia and its importance in shaping the socio-political climate in response to the crisis. Headcount poverty is a static concept as it is a snapshot of welfare conditions at any given point in time. In reality, however, poverty is a very fluid condition since it has been demonstrated that many households frequently move in and out of poverty (Bane \& Ellwood, 1986). The transient poor can also be defined as the households who have expected consumption levels above the poverty line with the risk that a household will become poor in the near future (Suryahadi \& Sumarto, 2001). A comparison of the findings with those of other studies confirmed that the majority of household incomes decreased by $60 \%$ during the COVID-19 pandemic. Furthermore, Figure 1 illustrated the average monthly expenditure versus the income of households before and during the pandemic, the majority (73\%) of our respondents are now living with only less than IDR 1 million a month, nearly impossible to cover their current living expense average (2.95 M IDR/month) for food, accommodation, and transportation. Considering the income households before the COVID-19 pandemic was around IDR 3.2 $\mathrm{M}$ per month, which was consistent with the Indonesian average monthly minimum wage of IDR 2.91 M (BPS, 2019), these are groups that are just falling into poverty that are directly attributable to the variability in consumption. The study consistently confirms the World Bank's (2019) assessment of Indonesia's middle-class vulnerability to poverty.

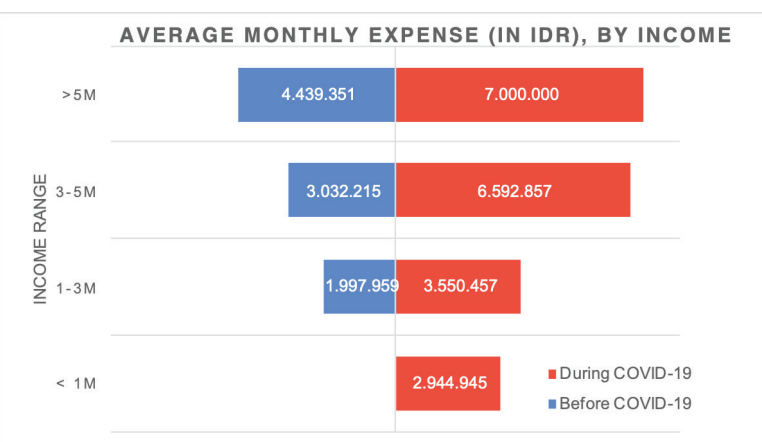

Figure 1. The Average Monthly Expense of Respondents by Income

In July 2020, relying on the data before the COVID-19 outbreak, Indonesia officially left the Lower-Middle Income status and became the Upper-Middle Class country since its gross national income (GNI) is now ranged between $\$ 4046$ to $\$ 12535$ (Akhlas, 2020a; Serajuddin \& Hamadeh, 2020). The increase of the GNI was driven by multiple factors; some of the notable facts are that the poverty rate of Indonesia has dropped below $10 \%$ in the last 15 years, while the middle-class population has grown from $7 \%$ to $20 \%$ of Indonesia's total population. Before the COVID-19 economy, 85\% of our respondents were the Middle Class, and 15\% were the Upper Class. The Middle-Class population according to SUSENAS and World Bank classification according to its per capita consumption per month is IDR 1.2-6.0 M. In contrast, the UpperClass population consumption per capita per month is more than IDR $6.0 \mathrm{M}$. With the current global pandemic, only a minority $(3 \%)$ of the respondents remain in the Middle Class while the rest are falling back into the Aspiring Middle Class and lower category.

One of the issues that emerge from these findings is that the Aspiring Middle Class is most likely struggling to re-enter the Middle 
Class due to the unpredictable shocks that affect household expenditures and income (World Bank, 2019). These are particularly challenging findings for the government to recover the economy. Conclusive with the literature, the survey indicates that the Middle Class has not yet achieved full economic security, implying their high vulnerability to poverty. Given the nature of COVID-19 and its transmission, containment and mitigation policies need to cover everyone while also recognizing that more impoverished people may be at greater risk of contracting COVID-19. Governments must also be sensitive to the short- and longerterm welfare impacts of the outbreak.

Since the NPI such as PSBB was enacted in April, the Indonesian government has given several fiscal stimulus packages such as Program Keluarga Harapan (PKH), social cash assistance for 9 million households outside Jakarta, Village Funds Unconditional Cash Transfer (BLT Dana Desa), and Pre-Employment Card (Kartu Prakerja) to cope with the impact of depleted national consumption (Ihsanuddin, 2020; Nuky, 2020; Prakerja, 2020; Rahman, 2020). Several mentions from our respondents indicate problems around the distribution of government aid ranging from technicality, formality, and registration issues. A possible explanation for these findings because government financial aid such as PKH and BLT require beneficiaries to provide proof of poverty issued by the local authority. This group of people is those who just entered the transient poverty status, which is overlooked in regional data due to the sudden impoverishing of welfare that happened during the COVID-19 pandemic.

Many respondents commented on the challenges of hybrid (development-cash transfer) Pre-Employment program (Kartu Prakerja) implementation. The program was implemented by the government to provide skill training for the workers to improve their skills to support employment opportunities, while they were also supported by financial aid when they finished the training (Prakerja, 2020). This program was critiqued by the Indonesian Corruption Watch as ineffective in increasing the employment rate as the training was given online while Indonesian digital literacy is still low and considers the low degree of job creation to absorb the workforce (Rahman, 2020; Ramadhan, 2020). This result may be explained by the fact that large groups of the impacted workers are not fully terminated from the job but are forced to take unpaid leave or payroll deduction; therefore, Pre-Employment Card that was prioritized for the terminated workers (Mukarohman, 2020) are not eligible for those who are still in the workforce but experiencing temporary pay cut or currently being suspended. Notwithstanding, Indonesia's Social Minister, Juliari Batubara was arrested due to a corruption suspect for COVID-19 social aid, moreover, the Indonesian Corruption Watch suspected that the corruption was planned before there was no COVID-19 case in Indonesia (Firdaus, 2021).

These findings suggest the unseen population is unserved by the monetary aid provided by the government among the other mismanaged social aids, impoverishing national and household-level capacities to influence the rate at which people escape from and remain out of poverty and their resilience to shocks. The unseen population, mainly from 
the Middle-Class that has political salience to economic and political reform (World Bank, 2019), might bring a negative impact on social cohesion (Lipset, 1959) and worsening the polarity between societal groups (Amoranto et al., 2010). Reflecting on Widodo's administration tendencies to eliminate opposition power by including the opposed parties to specific administrative roles, the counter-reformation from the opposition might not be an apparent threat to the ruling party. However, the more polarized and fractured society, the more burdensome it imparts for the nation in orchestrating shared values that need to be achieved to combat the Pandemic such as to support the successful vaccination program or even to support effective NPI measures like stay at home (Kariza, 2021). People's trust and confidence in good governance are important to ensure cooperative efforts in all layers of society to win the Pandemic fight. While the popularity of Jokowi remains the same among Indonesia citizens, the combination of lackluster response from the government in controlling the outbreak and some political changes that occurred during this pandemic such as the social aid corruption that entangled some politicians from the ruling party would highly affect the political climate in the upcoming election in 2024.

\section{Middle-Class Opportunities for In-Kind}

\section{Interventions}

Researchers attempted to evaluate the impact of COVID-19 on Indonesia's poverty (Suryahadi, Al, \& Suryadarma, 2020). It has been observed through various economic growth scenarios that Indonesia's poverty rate will grow by $0.5 \%$ at the end of 2020 if the impact of the ongoing pandemic on our economy is classified as mild, and will rise to $12.4 \%$ under the most severe projection. However, by looking at the COVID-19 pandemic toll on Indonesia's economy up until now, it has been argued that the impact of this is expected to be huge unless the virus is under control. In Quarter 2 of 2020, Indonesia's GDP experienced the biggest plunged ever since Quarter 2 of 1999 (Akhlas, 2020b). Using a historical approach to find out about the previous severe recession in Indonesia in 1998, it has been conclusively shown that it took Indonesia at least a year to finally be able to recover as the political and social condition was improved. In the previous recession in 1998, the crisis resulted in the falling of the Suharto regime that substantively made economic and political reformation in the Indonesian socio-political climate (Indonesia Investments, n.d.). Given the 2020 recession's condition that involves a global dimension with multilayers of population and directly correlates with general public health, it is prominent for other non-monetary stimuli to not only recover the economy as a national household but also to ensure the quality of welfare at the household level and therefore ensuring the political stability in Indonesia.

Several economic policy packages have been taken by the Indonesian government to immediately aid the plunge of the economic condition, such as the simplification of the existing rules that are related to imports and exports, free and discounted electricity for selected customer groups, exempted certain taxes for companies that affected by the health crisis, and restructuring and acceleration of the credits program to help small and medium 
enterprises (SMEs) (Embassy of The Republic of Indonesia in Brussels, 2020). The government also took controversial economic reform in law orchestration and restructuring called Omnibus Law to fasten the pace of the economic recovery (Lingga, 2020). The policy is expected to advantage employers by flexing the labor rules, simplifying the licensing and bureaucracy process to speed up job creations, and relaxing foreign investment restrictions (Pandjaitan, 2020). However, this policy is heavily critiqued by various groups of civil populations due to complicated political interests such as non-transparency in the procedural process (Sutiawan, 2020). Contradicting the government calculation, various points of view criticized the severe repercussions that could impact the attractiveness of Indonesian markets in foreign investment (Aldin, 2020), indicating ambiguous aims regarding the historical economic reform. This finding is positively related to the previous study (Nurshafira \& Alvian, 2018), supporting the views that Indonesia is leaning towards the formalist economy.

While the government has taken dramatic measures to navigate the uncertainty of the COVID-19 pandemic, the previous positive growth of the national economy has brought various opportunities to explore. The rising of the Middle-Class population altered the layer of society dimension; it affects the level of technology penetration, transforms market behavior and preferred channels, opens access to knowledge and higher education, and also enhances openness for innovation and entrepreneurship (Consumer Business, 2015; World Bank, 2019). Figure 2 from our surveys shows the level of education of our respondents that are majority from the Middle Class before the COVID-19 economy. The majority (65\%) of our respondents are high school graduates, followed by undergraduates (17\%) and diploma graduates $(15 \%)$.

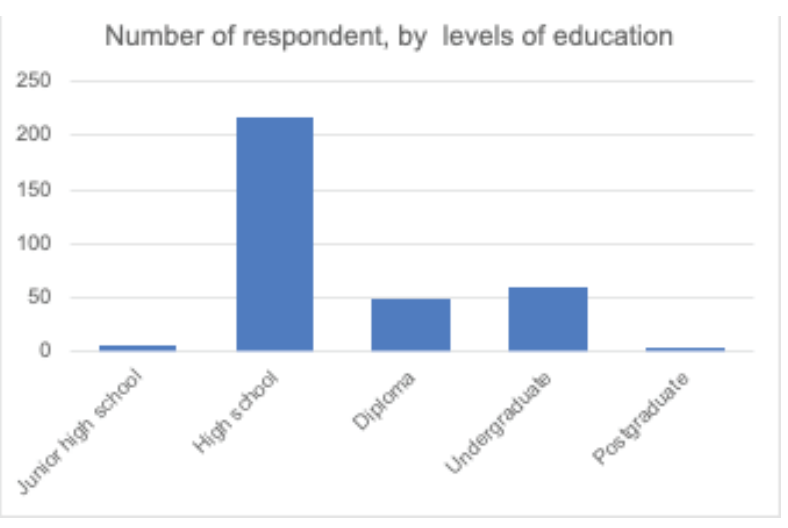

Figure 2. Level of Educations of the respondents

Looking at the geographical spread in Figure 3, 68\% of our respondents live in urban areas, while only $3 \%$ have moved to the second/ third-tier city during the COVID-19 pandemic. However, as illustrated in Figure 4, we observed a notable change in types of residence; the number of people who are living with their parents has risen (13\%) since COVID-19 happened as there is a decreasing number of respondents' who live in a rented house (18\%). This finding mainly indicates that the affected people can no longer afford the rent.

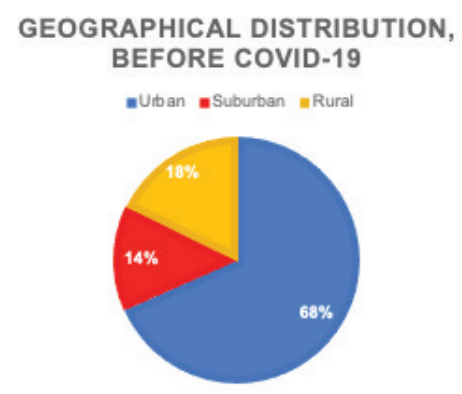

Figure 3. Geographical Distribution of the Respondents before COVID-19 


\section{residence ownership, before covid-19}

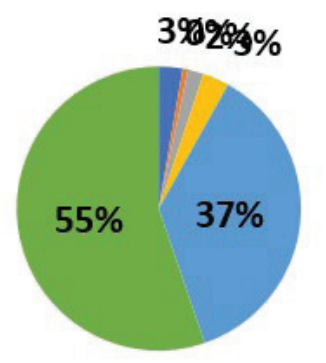

Provided by office

- Colleague's house

Others

Own house

- Parents' house

\section{residence ownership, AFTER COVID-19}

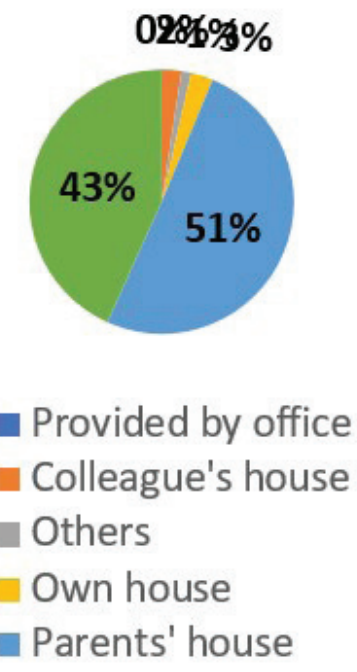

Figure 4. Residence Ownership of Respondents before and after COVID-19

The education level and geographical distribution of the respondents who were from the Middle Class indicates an opportunity to nurture the climate for job creation at the regional level through local entrepreneurship by focusing on innovation, the knowledge transfer process orchestration, and publicprivate partnership rather than relying on the external job creations. This is also in line with our survey that concluded entrepreneurial support is the most popular (71\%) choice rather than other non-monetary supports offered in the question such as job and training support or social assistance from the government.

$\begin{array}{cclc}\text { Several } & \text { studies } & \text { (Akbar \& } \\ \text { Arisaktiwardhana, } & 2019 ; & \text { Hartono } & \text { \& }\end{array}$
Kusumawardhani, 2018) concluded that Indonesian firms, like many other firms in developed economies, also employ open innovation practices in their innovation process, however, the involvement of private sector investment in innovation is still low. According to Aghion \& Akcigit (2018 as cited in Akbar \& Arisaktiwardhana, 2019) under the laissez-faire policies, supporting the formalist views where the government put minimum interference on the market, firms tend not to invest much in research and development. A study (Hamdani \& Wirawan, 2012) showed that Indonesian SMEs lack ideas, lack of partnership outside their cluster, and low usage of business development services due to lack of link and match.

This finding established the imperative of social-driven entrepreneurship to create countermovement in advocating substantivism views in the interplay of economic tensions. Social bricoleurs, who mainly characterized by operating on their own imposed social agenda (Zahra, Gedajlovic, Neubaum, \& Shulman, 2009) using tacit knowledge and 
available resources (Weick, 1993) to solve social issues, addressed the important role in maintaining balance in the market tensions and covering the socialization process to stabilize and to reproduce social and political orders. However, innovation facility and knowledge transfer orchestration for technology and knowledge exploration and exploitation to increase private sector contribution in innovation, thus supporting the common goal of COVID-19 recovery is a necessary intervention that needs to be facilitated by the government to nurture the market climate that will enable social bricoleurs in taking active participation in achieving the common goal of COVID-19 recovery.

Crafting Social Value Co-creation in Civil Solidarity through Social Bricoleur's Initiatives

One of the aims of this study was to explore the positive correlation between the active role of civil participatory and social value co-created through the lens of innovation theory principles. First, we explored the psychological impact of the ongoing COVID-19 situation on our respondents using the five phases of grief (Kübler-Ross, 1997) to assess the readiness for management of change in public stance. Although six months have passed since the first NPI was enacted, the majority of the survey $(35 \%)$ admitted that they are still in the denial phase, whilst $30 \%$ of the respondents are still struggling in despair. To deal with the COVID-19 crisis being a traumatic event evident by major social challenges, a social value co-creation perspective can be used to incorporate the multiple entities, including the profit and the non-profit organizations in society. Bridging the traditional commercial entrepreneurship activities with those that take a more societal view to profit creation (social entrepreneurship) will provide a way to focus on how social value objectives can be adopted within business activity and co-created amongst the society (Domenico \& Haugh, 2010). It allows the incorporation of more nonprofit or altruistic aims into community policies regarding the importance of social cohesion in society (Ratten, 2020). Smith, Barr, Barbosa, \& Kickul (2008) suggested that collaborative learning is required for the social value cocreation process; this will enable different segments of society, including individuals, private sectors, and the community, to learn together in crafting collaboration, solidarity, and other social initiatives in tackling multidimensional social problems. Due to the impact that COVID-19 has had on society, it is crucial to cultivate shared values and a culture of openness that thinks more about societal benefits rather than financial profit.

Chesbrough (2020) advocates a way to recover faster from the effects of COVID-19 using the combination of social value co-creation, social innovation, and entrepreneurship. Entrepreneurship can be used as a way to enact social value creation in society (Korsgaard \& Anderson, 2011). To this, it is necessary to create a proper business model approach that can monetize social value creation by including more relational coordination to exist amongst public-private partnerships (Caldwell, Roehrich, \& George, 2017). Rapid parallel experimentation on social innovation, support to entrepreneurship development, and orchestration of social value 
co-creation stakeholders are imperative to be given priority rather than the internal politics or bureaucratic process. Furthermore, Kuckertz et al. (2020) highlighted the importance of facilitating an open policy in disseminating information that will enable the collective use of human intelligence to solve or help alleviate a pressing social concern.

We noticed several sectoral themes that were mentioned by the respondents to answer what kind of opportunities could be ventured based on the skills of the respondents. Most of the ideas that were mentioned by the respondents revolved around sectoral interest themes such as food and beverages, services, logistic, and creative sectors. In the theory of cocreation, there are at least two main dimensions in social value co-creation, which are the degree of openness and the ownership of the outcomes created (Bayram, 2013). The higher degree of openness to collaboration and lower degree of private ownership of the outcomes created is the type that involved community. The community form of co-creation is the most relevant when developing something for the greater good where groups of people with similar interests and background themes can come together and co-create. Other types of co-creation processes can also be suitable for particular social challenges, such as forming a club of experts, using crowdsourcing to tackle social gaps, and forming coalition parties for specific shared social goals.

Given the enormous strides in interdependent global relations, the reversion back to local regions has had significant social policy implications. Quadruple helix (Curley \& Formica, 2013) collaboration that involves government, industry, university, and including the public who are actively participating in the co-creation process needs to be strengthened and to be facilitated on a state level. Several examples that Indonesian policymakers could learn from the developed countries such as the European Network of Living Lab (Almirall \& Wareham, 2011; Living Labs and Open Innovation, 2016) that was established by the European Commission and EU Presidency or Resilient Society initiative (Resilient Society, 2020). One could argue that the European power and attractiveness rest on the principle of solidarity and substantivism practices of the economy that are imperative to be adopted especially in facing the crisis. This Living Lab is a laboratory-based upon the idea of democratizing innovation (von Hippel, 1988) to support prototyping and experimenting center, which was intended to validate technology innovation in real user situations with the progression towards the quadruple helices setting. Furthermore, in the experimental centric space, there are several open innovation techniques that companies could use to boost the generation of innovation, namely by partnering with start-ups through acceleration programs, an open competition to generate new ideas, or co-innovation with the start-ups for new products and services (Mulas, 2017). Another example of innovation ecosystem management can be found in Resilient Society (www.resilientsociety.nl), where the government-initiated platform brings together coalitions of universities, companies, other governments, and many other organizations to combine their creativity, expertise, resources, and entrepreneurial spirits to develop new 
ideas, understandings product, and services in response to COVID-19 pandemic. These are government-led initiatives for enhancing social cohesion and improving technology and knowledge transfer by bringing society stakeholders to achieve shared social value, hence creating a more resilient community by facing multidimensional social problems in the COVID-19 pandemic.

Considering the complexion of social issues, multiple social profiles, and unequal distribution of opportunities due to geographical challenges in Indonesia, various social gaps are easily overlooked by the central authorities. It is an important area to be prioritized to enable local champions, individuals, who are social agents, and independent social ventures as they have unique positions in the social fabric that allows them to make an informed and intuitive judgment in addressing social equilibrium (Parsons, 1971) this is categorized by Zahra, Gedajlovic, Neubaum, \& Shulman (2009) in the spectrum of the social bricoleur. Social bricoleur in Indonesia uses tacit knowledge and available resources in their local area to venture opportunities as well as addressing local inequalities with their simple solution (Londa, 2019). With the lack of support in the Indonesian entrepreneurship ecosystem and pending legislation on social entrepreneurship legal instruments (DPR, 2018; Fasli, 2018), the findings from this study established the importance of social bricoleur as a model to inspire other local entrepreneurs to solve their social problem by venturing creativity. This characteristic can also be found in Bagirata, the social bricoleur initiative observed in this study. The movement itself indicates a civil initiative that uses social innovation and opensource technology in the attempts of wealth redistribution, which function should have been exercised by the government. However, due to the limitation of this study and the scale of the movement during the COVID-19 response, the correlation between the Bagirata initiative and the direct impact on the functioning of government remains largely unexamined.

\section{Conclusion}

Although the NPI implementation, such as stay-at-home or PSBB in Indonesia is only weakly associated with lower growth rates of confirmed cases of COVID-19, it is examined that the effect on the household level economy is dramatic. Using Bagirata as the data entry point, a form of social bricoleur, whose platform is used as collaborative learning tools to understand the social dynamics during COVID-19, we investigate community behavior and its current welfare. This study suggests that there are opportunities that emerge from the previous positive growth in social-economic class namely the appetite for entrepreneurship and significant potential for shared value cocreation orchestration. Although the findings should be interpreted with caution as it is limited by a relatively small sample, this study has established the importance of using entrepreneurship and innovation management strategy to alleviate the problems caused by COVID-19 to bring about positive changes and narrowing various societal gaps. This present study has offered a framework for the exploration of methods that can be used to enable social bricoleurs' collaboration in crafting civil solidarity through ecosystem 
orchestration and management. Whether or not the culture of solidarity and cooperation is still alive as it is claimed as the national identity, multi-dimensions civil solidarity empowered by the authority could be the key to not only survive the COVID-19 pandemic but also thriving further.

The government has taken various measures to assist common social welfare ranging from monetary (cash-transfer) intervention to massive economic reformation to recover the national economy. This study provides additional evidence on various underserved populations due to the lack of the government's data accuracy in distributing social support for intended beneficiaries. The findings of this research highlighted the importance of social bricoleur to use their tacit knowledge in detecting the unrecognizable social problem and to address the societal gap while venturing opportunities. This established the importance of balancing tensions in achieving economic recovery while the attempt to attend to multilayered social needs in the context of the COVID-19 Pandemic. Especially in Indonesia, where economic-political views are inclined towards a formalist approach, in this sense, the paper argues that balancing towards a more substantivism approach is imperative in COVID-19 fight discourse. Lastly, this paper suggests various methods from innovation theories to enable social bricoleur as an act of civil participation in crafting the Pandemic solidarity, however, the findings fail to demonstrate supporting evidence that indicates a direct positive impact on the improvement of good governance during the COVID-19 response.
With the political conflicts that happened in the Global South during the pandemic, despite its exploratory nature, these findings offer some insight for practitioners and policymakers in initiating social value co-creation in response to the COVID-19 pandemic. The COVID-19 situation has been a shock for almost the global population; however, while solidarity has been called by many to emphasize that we are floating in the same global problems, it's clear that some of us are in the superyacht while others are clinging to drifting debris. The main focus for COVID-19 solidarity calls should demonstrate inclusivity, orchestrated with clear political commitments to nurture all efforts of social improvement that are crafted on the democratize collective efforts of social agents. Economic recovery should aim beyond national GDP and general public health management. How the COVID-19 pandemic will affect society in the long future is still unknown; what is known is that society will never be the same as it was before. An innovative political mindset that will radically increase social cohesion to achieve shared social values should be given more attention. Incorporating social value cocreation initiatives in how they deal with the effects of COVID-19 will help to narrow the gap within communities and to serve the unseen population, thus enhancing their resilience and coherence in handling the COVID-19 pandemic. Transformational leadership in multi-society dimensions is required to connect all resources while building social cohesion and stability that will turn drive growth further, rather than focusing on a strategic priority that has the risk of impoverishing the degree of fractiousness in Indonesian polarized society. 
Social value co-creation should be enabled through shared value orchestration, quadruple helices initiative, and innovation ecosystem management that empowers individual and institutional bricoleurs to accelerate the pace of COVID-19 recovery beyond the aggregate point of view.

\section{References}

\section{Books}

Chesbrough, H. (2003). Open Innovation : The New Imperative for Creating and Profiting from Technology. Boston, Mass.: Harvard Business School Press.

Kübler-Ross, E. (1997). On Death and Dying. Simon \& Schuster/Touchstone Book. Retrieved from https://books. google.co.uk/books/about/On Death_and_Dying.html?id=H-Ye AgAAQBAJ\&printsec $=$ frontcove r\&source $=k p \_r e a d \_b u t t o n \& r e d i r$ $\mathrm{esc}=\mathrm{y} \# \mathrm{v}=$ onepage $\& \mathrm{q} \& \mathrm{f}=$ false

Parsons, T. (1971). The system of modern societies. Englewood Cliffs, NJ: Prentice-Hall.

Pfeffer, J., \& Salancik, G. R. (2003). The external control of organizations: A resource dependence perspective. Stanford University Press.

Von, E. A. (1988). Sources of Innovation. Oxford: Oxford University Press. Retrieved from https://papers.ssrn. com/sol3/papers.cfm?abstract $\mathrm{id}=2877276$

\section{Report}

Consumer Business. (2015). Deloitte Consumer
Insights Capturing Indonesia's latent markets.

Deloitte. (2020). Combating COVID-19 with an agile change management approach.

OECD. (2017). OECD Reviews of Innovation Policy: Norway 2017. Norway: OECD. https://doi. org/10.1787/9789264277960-en

Suryahadi, A., Al, R., \& Suryadarma, I. D. (2020). The Impact of COVID-19 Outbreak on Poverty: An Estimation for Indonesia. Retrieved from www.smeru.or.id.

Suryahadi, A., \& Sumarto, S. (2001). The Chronic Poor, the Transient Poor, and the Vulnerable in Indonesia Before and After the Crisis.

World Bank. (2019). Aspiring IndonesiaExpanding the Middle Class. Washington, DC. Retrieved from https://openknowledge.worldbank. org/handle/10986/33237

World Health Organization. (2020). Critical preparedness, readiness and response actions for COVID-19., (March), 1-3.

\section{Thesis/Dissertation}

Londa, I. (2019). Enabling Social Enterprises in Indonesia (Unpublished master's dissertation). University of Warwick, Coventry, United Kingdom.

\section{Journal Article (retrived online, with DOI)}

Aghion, P., \& Akcigit, U. (2018). Innovation and growth from a schumpeterian 
perspective. Revue d'Economie

Politique (Vol. 128). https://doi. org/10.3917/redp.285.0693

Almirall, E., \& Wareham, J. (2011). Living Labs: arbiters of mid- and groundlevel innovation. Technology Analysis \& Strategic Management, 23(1), 87-102. https://doi.org/10.1 080/09537325.2011.537110

Amoranto, G., Chun, N., \& Deolalikar, A. (2010). Who are the middle class and what values do they hold? Evidence from the world values survey. ADB Economics Working Paper Series, 229, 1-29. https:// doi.org/10.2139/ssrn. 1743180

Askary, P., \& Fallah, F. (2020). The Right to International Solidarity and Humanitarian Assistance in the Era of covid-19 Pandemic. Journal of International Humanitarian Legal Studies, 11(2), 193-203. https://doi.org/10.1163/18781527bja10018

Bane, M., \& Ellwood, D. (1986). Slipping Into and Out Of Poverty: The Dynamics of Spells. Journal of Human Resources, 21, 1-23. https://doi. org/10.2307/145955

Barro, R., Ursúa, J., \& Weng, J. (2020). The Coronavirus and the Great Influenza Pandemic: Lessons from the "Spanish Flu" for the Coronavirus's Potential Effects on Mortality and Economic Activity. Cambridge, MA. https://doi. org/10.3386/w26866

Caldwell, N., Roehrich, J., \& George, G.
(2017). Social Value Creation and Relational Coordination in PublicPrivate Collaborations. Journal of Management Studies, 54(6), 906-928. https://doi.org/10.1111/ joms. 12268

Chesbrough, H. (2020). To recover faster from Covid-19, open up: Managerial implications from an open innovation perspective. Industrial Marketing Management, 88, 410413. https://doi.org/10.1016/j. indmarman.2020.04.010

Curley, M., \& Formica, P. (2013). The Experimental Nature of New Venture Creation Capitalizing on Open Innovation 2.0. https://doi. org/10.1007/978-3-319-00179-1

Curley, M., \& Salmelin, B. (2013). Open Innovation 2.0: A New Paradigm. OISPG White Paper, 1-12. https:// doi.org/10.1109/HIS.2008.172

Curley, M., \& Salmelin, B. (2018). Open Innovation 2.0. Cham: Springer International Publishing. https:// doi.org/10.1007/978-3-319-628783

Domenico, M., \& Haugh, H. (2010). Social Bricolage: Theorizing Social Value Creation in Social Enterprises. Entrepreneurship: Theory and Practice, 34. https://doi.org/10.1111/j.15406520.2010.00370.x

Hamdani, J., \& Wirawan, C. (2012). Open Innovation Implementation to Sustain Indonesian SMEs. Procedia Economics and Finance, 4(Icsmed), 
223-233. https://doi.org/10.1016/ s2212-5671(12)00337-1

Hartono, A., \& Kusumawardhani, R. (2018). Searching Widely or Deeply? the Impact of Open Innovation on Innovation and Innovation Performance Among Indonesian Manufacturing Firms. Journal of Indonesian Economy and Business, 33(2), 123. https://doi. org/10.22146/jieb.29218

Hatchett, R. J., Mecher, C. E., \& Lipsitch, M. (2007). Public health interventions and epidemic intensity during the 1918 influenza pandemic. Proceedings of the National Academy of Sciences, 104(18), 7582 LP - 7587. https://doi. org/10.1073/pnas.0610941104

Jalan, J., \& Ravallion, M. (2007). Is Transient Poverty Different? Evidence for Rural China. The Journal of Development Studies, 36, 82-99. https://doi. org/10.1080/00220380008422655

Korsgaard, S., \& Anderson, A. (2011). Enacting entrepreneurship as social value creation. International Small Business Journal - INT SMALL BUS J, 29(2), 135-151. https://doi. org/10.1177/0266242610391936

Kuckertz, A., Brändle, L., Gaudig, A., Hinderer, S., Morales Reyes, C. A., Prochotta, A., ... Berger, E. S. C. (2020). Startups in times of crisis A rapid response to the COVID-19 pandemic. Journal of Business Venturing Insights, 13, e00169- e00169. https://doi.org/10.1016/j. jbvi.2020.e00169

Lipset, S. M. (1959). Some Social Requisites of Democracy: Economic Development and Political Legitimacy. The American Political Science Review, 53(1), 69-105. https://doi.org/10.2307/1951731

Markel, H., Lipman, H. B., Navarro, J. A., Sloan, A., Michalsen, J. R., Stern, A. M., \& Cetron, M. S. (2007). Nonpharmaceutical interventions implemented by US cities during the 1918-1919 influenza pandemic. Journal of the American Medical Association, 298(6), 644-654. https://doi.org/10.1001/ jama.298.6.644

Munshi, N. V. (2010). Value Creation, Social Innovation, and Entrepreneurship in Global Economies. Journal of Asia-Pacific Business, 11(3), 160165. https://doi.org/10.1080/10599 231.2010.500569

Nurshafira, T., \& Alvian, R. A. (2018). Political-Economy of Social Entrepreneurship in Indonesia: A Polanyian Approach. Jurnal Ilmu Sosial Dan Ilmu Politik, 22(2), 2502-7883. https://doi. org/10.22146/jsp.27942

Ratten, V. (2020). Coronavirus (covid-19) and social value co-creation. International Journal of Sociology and Social Policy, aheadof-p. https://doi.org/10.1108/ IJSSP-06-2020-0237

Simarmata, N., Wahyu Yuniarti, K., Riyono, 
B., Patria, B., Saklofske, D. H., Ismail, R., \& Lahlou, S. (2020). Gotong Royong in Indonesian History Gotong Royong in Indonesian History. Digital Press Social Sciences and Humanities, 5, 6. https://doi.org/10.29037/ digitalpress.45341

Smith, B. R., Barr, T. F., Barbosa, S. D., \& Kickul, J. R. (2008). SOCIAL ENTREPRENEURSHIP: A GROUNDED LEARNING APPROACH TO SOCIAL VALUE CREATION. Journal of Enterprising Culture, 16(04), 339-362. https://doi.org/10.1142/ s0218495808000235

Weber, M. (2007). The Concept of Solidarity in the Study of World Politics: Towards a Critical Theoretic Understanding. Review of International Studies, 33(4), 693713. Retrieved from http://www. jstor.org/stable/20097967

Zahra, S. A., Gedajlovic, E., Neubaum, D. O., \& Shulman, J. M. (2009). A typology of social entrepreneurs: Motives, search processes and ethical challenges. Journal of Business Venturing, 24(5), 519532. https://doi.org/10.1016/j. jbusvent.2008.04.00

\section{Journal Articles (retrieved online, without} DOI or page numbers)

Ceylan, R., \& Ozkan, B. (2020). The economic effects of epidemics: From SARS and MERS to COVID-19, 1, 21-
29.

Hayek, F. A. (1945). The Use of Knowledge in Society. The American Economic Review (Vol. 35). Retrieved from http://static.stevereads. com/papers_to_read/the_use_of_ knowledge_in_society.pdf

Weick, K. E. (1993). The collapse of sensemaking in organizations: The Mann Gulch disaster. Administrative Science Quarterly, 38, 628-652. Retrieved from http:// www.cs.unibo.it/ ruffino/Letture TDPC/K. Weick - The collapse of sensemaking.pdf

\section{Newspaper Article}

Akhlas, W. (2020a, July 2). Indonesia now upper middle-income country, World Bank says - Business - The Jakarta Post. Retrieved October 25, 2020, from https://www.thejakartapost. com/news/2020/07/02/indonesianow-upper-middle-incomecountry-world-bank-says.html

Akhlas, W. (2020b, August 5). Indonesia's GDP contracts deeper than expected at $5.32 \%$ in Q2 - Business - The Jakarta Post. The Jakarta Post. Retrieved from https://www.thejakartapost. com/news/2020/08/05/indonesiasgdp-contracts-deeper-thanexpected-at-5-32-in-q2.html

CNN Indonesia. (2020, May 1). Bukan 2 Juta, Kadin Sebut Korban PHK Akibat Corona 15 Juta. Retrieved October 24, 2020, from https:// www.cnnindonesia.com/ekono 
$\mathrm{mi} / 20200501181726-92-499298 /$

bukan-2-juta-kadin-sebut-korbanphk-akibat-corona-15-juta

Da Costa, A., \& Lamb, K. (2020, December 30). Indonesia bans hardline Islamic Defender's Front group. Reuters. Retrieved from https://www. reuters.com/article/us-indonesiasecurity-idUSKBN2940FM

Fasli, Z. (2018, August 20). Menteri Mangkir, Rapat Kosultasi RUU Kewirausahaan Nasional Ditunda - $\quad$ LIPUTAN.CO.ID. Retrieved October 25, 2020, from https:// liputan.co.id/2018/08/menterimangkir-rapat-kosultasi-ruukewirausahaan-nasional-ditunda/

Firdaus, I. (2021, February 3). Dugaan Korupsi Bansos Sudah Dirancang Pejabat Kemensos dan Politikus PDIP Sebelum Pandemi. Kompas. Retrieved from https://www. kompas.tv/article/143658/dugaankorupsi-bansos-sudah-dirancangpejabat-kemensos-dan-politikuspdip-sebelum-pandemi? page $=2$

Gorbiano, I. (2020a, May 19). COVID-19 crisis exposes holes in social aid disbursement-National-TheJakarta Post. Retrieved October 25, 2020, from https://www.thejakartapost. com/news/2020/05/19/covid-19crisis-exposes-holes-in-social-aiddisbursement.html

Gorbiano, I. (2020b, May 28). Cash aid disbursement fails to meet Idul Fitri target - National - The Jakarta Post. The Jakarta Post. Retrieved from https://www.thejakartapost. com/news/2020/05/28/cash-aiddisbursement-fails-to-meet-idulfitri-target.html

IDNFinancials. (2020, September 2). Recession inevitable, says Sri Mulyani . Retrieved October 24, 2020, from https://www.idnfinancials.com/ news/35957/recession-inevitablesri-mulyani

Ihsanuddin, I. (2020, August 26). Ada 7 Bantuan Pemerintah Selama Pandemi Covid-19, Berikut Riciannya. Kompas.Com. Retrieved from https://nasional.kompas.com/ $\mathrm{read} / 2020 / 08 / 26 / 09222471 / \mathrm{ada}-$ 7-bantuan-pemerintah-selamapandemi-covid-19-berikutrinciannya?page $=$ all

Jiao, C., \& Sihombing, G. (2021, February 18). Bank Indonesia Cuts Rates and Outlook as the Recovery Stalls Bloomberg. Bloomberg. Retrieved from https://www.bloomberg.com/ news/articles/2021-02-18/bankindonesia-delivers-rate-cut-aseconomic-recovery-stalls

Lingga, V. (2020, October 7). Omnibus law: Biggest 'big bang' reform ever - Opinion - The Jakarta Post. The Jakarta Post. Retrieved from https://www.thejakartapost.com/ academia/2020/10/07/omnibuslaw-biggest-big-bang-reform-ever. html

Mukarohman, F. (2020, August 9). Aturan Baru, Siapa Saja yang Bisa Mendapat Kartu Prakerja? 
Kompas.Com. Retrieved from https://www.kompas.com/tren/ $\mathrm{read} / 2020 / 08 / 09 / 180300865 /$ aturan-baru-siapa-saja-yangbisa-mendapat-kartu-prakerja?page $=$ all

Pangastuti, T. (2020, November 23). Indonesia Is Unlikely to Escape Recession: Finance Minister. Retrieved October 24, 2020, from https://jakartaglobe.id/business/ indonesia-is-unlikely-to-escaperecession-finance-minister

Rahman, F. (2020, May 5). Preemployment card draws criticism as workers 'need cash aid' - Business The Jakarta Post. Retrieved October 25, 2020, from https:// ww w.thejakartapost.com/ news/2020/05/04/preemploymentcard-draws-criticism-as-workersneed-cash-aid.html

Ramadhan, A. (2020, April 17). Kartu Prakerja Dinilai Bukan Solusi Tepat Bagi Pekerja Informal di Tengah Pandemi. Kompas.Com. Retrieved from https://nasional.kompas.com/ $\mathrm{read} / 2020 / 04 / 17 / 21095611 / \mathrm{kartu}-$ prakerja-dinilai-bukan-solusitepat-bagi-pekerja-informal-ditengah?page $=$ all

Shalihah, F. (2020, July 18). Kasus Infeksi Virus Corona di Thailand Rendah, Apa Penyebabnya? Halaman all - Kompas.com. Kompas.Com. Retrieved from https://www.kompas.com/tren/ $\mathrm{read} / 2020 / 07 / 18 / 100000665 /$ kasus-infeksi-virus-corona-dithailand-rendah-apa-penyebabnya?page $=$ all

Sutiawan, I. (2020, February 13). Omnibus Law, Serikat Pekerja: Pemerintah Tak Transparan | Ekonomi. Gatra. Com. Retrieved from https://www. gatra.com/detail/news/469057/ ekonomi/omnibus-law-serikatpekerja-pemerintah-tak-transparan Tri, R. (2020, September 11). PSBB Jakarta Jilid II, Peneliti Sebut Ekonomi Akan Kembali Minus - Bisnis Tempo.co. Tempo.Co. Retrieved from https:// bisnis.tempo.co/read/1385115/ psbb-jakarta-jilid-ii-peneliti-sebutekonomi-akan-kembali-minus

Utama, A. (2020, August 9). Covid-19 dan gerakan berbagi penghasilan saat pandemi, "jangan anggap pemerintah penolong yang utama" - BBC News Indonesia. Retrieved October 24, 2020, from https://www.bbc.com/indonesia/ indonesia-53696060

Voi Editorial Team. (2020, December 12). Sandiaga Uno Becomes Minister Of Tourism And Creative Economy, Minister Of Health Terawan Is Removed. VOI. Retrieved from https://voi.id/en/berita/23952/ sandiaga-uno-jadi-menteripariwisata-dan-ekonomi-kreatifmenkes-terawan-dicopot

Xie, J. (2020, May 6). After COVID-19, China's Global Stature on the Line . Voice of America . Retrieved from https://www.voanews.com/ 
covid-19-pandemic/after-covid-

19-chinas-global-stature-line

\section{Audiovisual media (videos, music} recordings, podcast, etc.)

MetroTV. (2020, September 7). Bagirata, Platform Patungan Bantu Pekerja Terdampak Covid-19 - www. metrotvnews.com. Retrieved from https://www.metrotvnews. com/play/Ky6CmBYX-bagirataplatform-patungan-bantu-pekerjaterdampak-covid-19

\section{Electronic Source}

Akbar, I., \& Arisaktiwardhana, D. (2019). Indonesia's quest for innovations requires more funding from private sectors. Retrieved October 24,2020, from https://theconversation.com/ indonesias-quest-for-innovationsrequires-more-funding-fromprivate-sectors-113951

Aldin,U.(2020).InvestorGlobalKritikOmnibus Law - Keuangan Katadata.co.id. Retrieved October 25, 2020, from https://katadata.co.id/safrezifitra/ finansial/5f7c3b1742c85/investorglobal-kritik-omnibus-law

Bayram, A. S. (2013). How Co-Creation Impacted businesses. Retrieved October 25, 2020, from https:// ahmadsb.com/how-co-creationimpacted-businesses/

BPS. (2019). Berapa Rata-Rata Gaji Pekerja di Indonesia? | Databoks. Retrieved October 25, 2020, from https://databoks.katadata.co.id/ datapublish/2019/11/06/beraparata-rata-gaji-pekerja-di-indonesia

British Council. (2017). Active Citizens. Retrieved February 22, 2021, from https://www.britishcouncil.org/ sites/default/files/active_citizens_ global_toolkit_2017-18.pdf

Dalton, R. (2017). Is citizen participation actually good for democracy? - Retrieved February 22, 2021, from https://www.democraticaudit. com/2017/08/22/is-citizenparticipation-actually-good-fordemocracy/

DPR, P. K. (2018). Menteri Tak Hadir, Rapat Konsultasi RUU Kewirausahaan Nasional Ditunda. Retrieved from http://www.dpr.go.id/berita/detail/ id/21741/t/Menteri+ Tak+Hadir $\% 2 \mathrm{C}+$ Rapat+Kosultasi+RUU+ Kewirausahaan+Nasional+Ditunda Embassy of The Republic of Indonesia in Brussels, B. (2020). POLICIES BY THE INDONESIAN GOVERNMENT RELATED TO THE CORONAVIRUS (COVID-19) PANDEMIC. Retrieved October 25, 2020, from https://kemlu.go.id/brussels/ en/news/6349/policies-by-theindonesian-government-relatedto-the-Coronavirus-covid-19pandemic

Fonteneau, Bénédicte, Leandro, K., \& Morais, P. (2020). "Social and Solidarity Economy: Building a Common Understanding." (B Fonteneau, N. Neamtan, F. Wanyama, \& 
L. Morais, Eds.) (First edition). Turin: International Training Centre of the International Labour Organization. Retrieved from http://www.socioeco.org/bdf fiche-document-5048_en.html

Gaztambide-Fernández, R. A. (2020) What is solidarity? During coronavirus and always, it's more than "we're all in this together." Retrieved February 22, 2021, from https:// theconversation.com/what-issolidarity-during-coronavirus-andalways-its-more-than-were-all-inthis-together-135002

Indonesia Investments. (n.d.). Krisis Keuangan Asia - Krismon - Sebab \& Dampak . Retrieved February 22, 2021, from https://www.indonesiainvestments.com/id/budaya/ ekonomi/krisis-keuangan-asia/ item 246

Kariza, A. (2021). Tiga hal penting untuk menyukseskan vaksinasi COVID-19 dari sudut pandang ekonomi perilaku. Retrieved February 22, 2021, from https://theconversation. com/tiga-hal-penting-untukmenyukseskan-vaksinasi-covid19-dari-sudut-pandang-ekonomiperilaku-154086

Living Labs and Open Innovation. (2016). Shaping Europe's digital future. Retrieved October 25, 2020, from https://ec.europa.eu/digital-singlemarket/en/news/living-labs-andopen-innovation
Ministry of Foreign Affairs of the Republic of Indonesia. (2020). Indonesia Successfully Passes The First Un Resolution On Global Solidarity To Overcome Covid 19 | Portal Kementerian Luar Negeri Republik Indonesia. Retrieved February 22, 2021, from https://kemlu. go.id/portal/en/read/1160/view/ ind onesia-successfully-passesthe-first-un-resolution-on-globalsolidarity-to-overcome-covid-19

Mulas, V. (2017). Corporate Innovation 2.0: How companies are creating new products and services to compete in the all-tech age | Private Sector Development. Retrieved December 9, 2018, from https://blogs. worldbank.org/psd/corporateinnovation-20-how-companiesare-creating-new-products-andservices-compete-all-tech-age

Nuky, E. (2020). Inilah Daftar Semua Bantuan Pemerintah untuk Orang Miskin Hingga Pengusaha Kaya. Retrieved October 24, 2020, from https:// investor.id/business/inilah-daftarsemua-bantuan-pemerintah-untukorang-miskin-hingga-pengusahakaya

Pandjaitan, M. (2020). Omnibus Law in Indonesia [Brought to you by IABF] | Asian Legal Business. Retrieved October 25, 2020, from https://www.legalbusinessonline. com/omnibus-law-indonesiabrought-you-iabf

Pepinsky, T. (2021). COVID-19 and democracy 
in Indonesia: Short-term stability and long-term threats. Retrieved February 22, 2021, from https:// www.brookings.edu/blog/orderfrom-chaos/2021/01/26/covid19-and-democracy-in-indonesiashort-term-stability-and-longterm-threats/

Perthes, V. (2020). The Corona Crisis and International Relations: Open Questions, Tentative Assumptions. Retrieved February 22, 2021, from https://www.swp-berlin.org/ en/publication/the-corona-crisisand-international-relations-openquestions-tentative-assumptions/

Porter, M. E., \& Kramer, M. R. (2011). Creating Shared Value. Retrieved December 7, 2018, from https:// hbr.org/2011/01/the-big-ideacreating-shared-value

Prakerja. (2020). Kartu Prakerja - Melalui Kartu Prakerja, Pemerintah bantu 5.6 juta pekerja yang terkena dampak langsung dari wabah COVID-19 [Press Release]. Retrieved October 25, 2020, from https://www.prakerja.go.id/pressrelease/melalui-kartu-prakerjapemerintah-bantu-5-6-jutapekerja-yang-terkena-dampaklangsung-dari-wabah-covid-19

Resilient Society. (2020). Find partners \& co-create solutions - Response and recovery for the COVID-19 pandemic. Retrieved October 25, 2020, from https://resilientsociety. $\mathrm{nl} /$
Santiago, C. (2020). The COVID New (Ab) Normal: Post-COVID-19 ASEAN and the Centrality of Human Rights . Retrieved February 22, 2021, from https://asiasociety. org/policy-institute/covid-newabnormal-post-covid-19-aseanand-centrality-human-rights

Serajuddin, U., \& Hamadeh, N. (2020). New World Bank country classifications by income level: 2020-2021. Retrieved October 25, 2020, from https://blogs.worldbank. org/opendata/new-world-bankcountry-classifications-incomelevel-2020-2021

Spier, J. (2020). In Africa, Civil Rights vs. a Heavy-Handed Pandemic Response | Voice of America - English. Voice of America . Retrieved from https:// www.voanews.com/episode/africacivil-rights-vs-heavy-handedpandemic-response-4297591

Unesco Institute for Statistics. (n.d.). How much does your country invest in R\&D?. Retrieved October 24, 2020, from http://uis.unesco.org/ apps/visualisations/research-anddevelopment-spending/

World101. (2021). Eighteen Ways COVID-19 Is Reshaping the World. Retrieved February 22, 2021, from https:// world101.cfr.org/global-era-issues/ covid-19/eighteen-ways-covid-19reshaping-world 